\title{
Pengaruh Kualitas Pelayanan, Pengiklanan Dan HargaTerhadap Keputusan Konsumen Dalam Memilih Go-Food
}

\author{
Faomasi Ndruru ${ }^{1}$, Trimartha Sihombing ${ }^{2}$, Fenny Krisna Marpaung ${ }^{3}$ \\ Fakultas Ekonomi, Universitas Prima Indonesia \\ fennykrisnamarpaung@unprimdn.ac.id
}

\begin{abstract}
This study aims to examine and analyze the effect of service quality, advertising and price on consumer decisions in choosing Go-Food. This research was conducted on 24 consumers or Go-Food customers in Medan City. Based on the results of this study, it is known that service quality, advertising and price have a significant positive effect on consumer decisions in choosing Go-Food. Go-Food must be able to maintain or continue to improve the quality of its service, because of the good quality of service, maintain or continue to develop creativity for advertising, and increase price competitiveness, because current prices are able to have a positive influence on consumer decisions to choose Go-Food.
\end{abstract}

Keyword: Service Quality, Advertising, Price, Consumer Decisions

\section{BAB 1. PENDAHULUAN}

\section{Latar Belakang Masalah}

Perkembangan dan kemajuan teknologi informasi saat ini telah merambah ke bidang transportasi untuk mempermudah aktivitas manusia. Dengan kemajuan dan perkembangan tersebut seiring berjalannya waktu, transportasi kemudian dijadikan salah satu bisnis dalam sektor jasa. Dengan meningkatnya kebutuhan akan moda transportasi yang cepat dan mudah maka munculah bisnis jasa layanan transportasi online menggunakan aplikasi.

Pemanfaatan teknologi dalam bidang transportasi memberikan kemudahan dalam pemesanan, efisiensi waktu, dan biaya sehingga menjadi kelebihan tersendiri bagi penyedia layanan jasa transportasi online dibandingkan dengan transportasi konvensional. Pada awal kemunculan transportasi online tersebut menuai pro dan kontra karena transportasi konvensional kalah bersaing dengan transportasi online. Saat ini sudah banyak penyedia jasa layanan transportasi online yang salah satunya adalah GoJek.

Tidak hanya sebagai sarana transportasi saja, namun Go-Jek juga menyediakan layanan pesan antara makanan sebagai salah satu layanan andalannya, yaitu G-Food. Go-Food adalah layanan pesan antar makanan terbesar di dunia di luar Cina dan bekerja sama dengan 400,000 merchant di berbagai Kota di Indonesia. Terdapat lebih dari 400,000 restoran telah menjadi Go-Food Partner dan resmi bekerja sama dengan GoFood (Gojek.com, 2019).

Meski demikian, pihak manajemen Go-Jek harus selalu tetap memperhatikan faktor-faktor apa saja yang mampu meningkatkan keputusan konsumen untuk memilih layanan Go-Food, sehingga perusahaan terus dapat bersaing dan bertahan seiring waktu dengan banyaknya pesaing. Melihat bahwa Go-Food merupakan layanan pesan antar 
makanan sudah pasti yang utama dinilai konsumen adalah kualitas pelayanan. Kualitas pelayanan yang baik memberikan nilai positif di mata konsumen, sehingga konsumen tidak akan ragu memilih suatu layanan apabila pelayanan yang diberikan berkualitas. Selain kualitas layanan, pengiklanan juga merupakan faktor penting, karena dengan adanya iklan, maka konsumen akan lebih sadar akan keberadaan suatu produk maupun layanan, karena dengan adanya iklan yang menarik, maka konsumen akan melirik produk atau layanan tersebut. Selanjutnya adalah harga, yang merupakan hal yang sangat menentukan dalam menjual suatu produk atau layanan, dengan harga yang bersaing atau sesuai dengan apa yang diperoleh konsumen, maka konsumen tidak akan ragu untuk memilih layanan tersebut.

\section{Rumusan Masalah}

Berdasarkan uraian latar belakang masalah dalam penelitian ini dapat dirumuskan masalah sebagai berikut:

a. Apakah kualitas pelayanan berpengaruh terhadap keputusan konsumen dalam memilih Go-Food?

b. Apakah pengiklanan berpengaruh terhadap keputusan konsumen dalam memilih Go-Food?

c. Apakah harga berpengaruh terhadap keputusan konsumen dalam memilih GoFood?

d. Apakah kualitas pelayanan, pengiklanan, dan harga berpengaruh simultan terhadap keputusan konsumen dalam memilih Go-Food?

\section{KAJIAN LITERATUR}

\section{Kualitas Pelayanan}

Menurut Tjiptono (2016: 268) kualitas pelayanan berfokus pada upaya pemenuhan kebutuhan dan keinginan konsumen serta ketepatan penyampaianya untuk mengimbangi harapan konsumen.

\section{Pengiklanan}

Menurut Moriaty, Mitchell, \& Wells (2014: 9) iklan atau pengiklanan adalah bentuk komunikasi berbayar yang menggunakan media massa dan media interaktif untuk menjangkau audiens yang luas dalam rangka menghubungkan sponsor yang jelas dengan pembeli (audiens sasaran) dan memberikan informasi tentang produk (barang, jasa, dan gagasan).

\section{Harga}

Menurut Kotler \& Keller (2016: 430) harga adalah sejumlah uang yang dibayarkan atas barang dan jasa, atau jumlah nilai yang konsumen tukarkan dalam rangka mendapatkan manfaat dari memiliki atau menggunakan barang atau jasa.

\section{Keputusan Konsumen}

Keputusan konsumen untuk memilih dan menggunakan adalah istilah lain dari keputusan pembelian yang merupakan bagian dari perilaku konsumen. Dimana perilaku konsumen sendiri merupakan tindakan-tindakan individu yang secara langsung terlibat dalam mengevaluasi juga usaha memperoleh, menggunakan dan menentukan produk dan jasa. Keputusan pembelian merupakan tahap evaluasi, konsumen dari preferensi di antara merek di set pilihan dan mungkin juga dari niat untuk membeli merek yang 
paling disukai (Kotler \& Armstrong, 2014: 170).

\section{Kerangka Konseptual}

Setiap konsumen memiliki pertimbangan tersendiri sebelum mengambil keputusan untuk membeli atau menggunakan suatu produk dan jasa. Beberapa hal diantaranya adalah kualitas dari pelayanan yang diberikan, pengikalan, dan harga. Sehingga ketiga hal tersebut menjadi 3 (tiga) diantara beberapa faktor yang memiliki pengaruh terhadap keputusan konsumen. Melalui hal tersebut dapat digambarkan kerangka konseptual sebagai berikut:

\section{Gambar 1.}

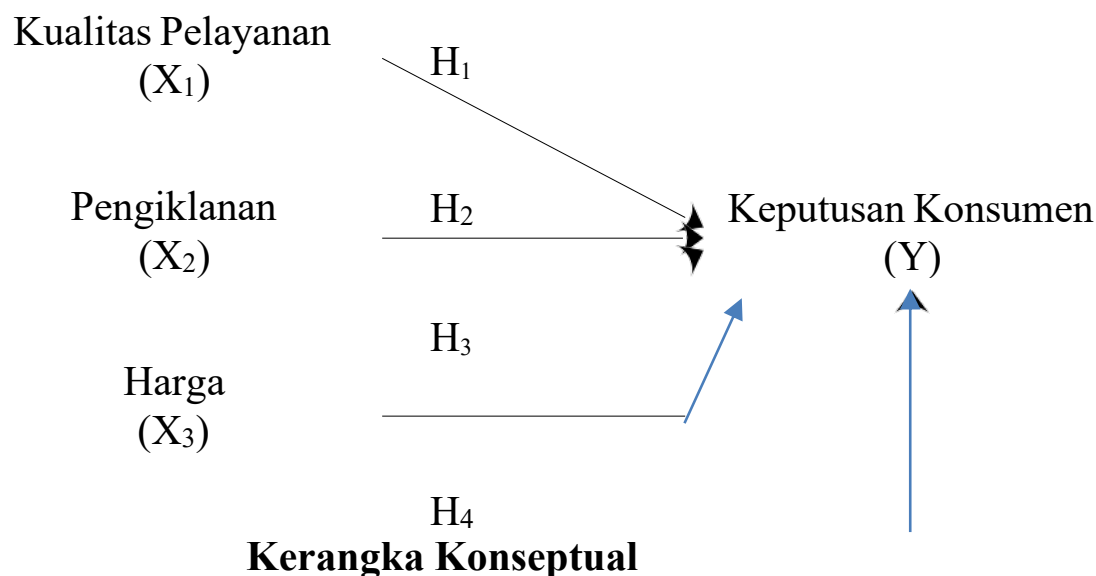

\section{Hipotesis Penelitian}

Berdasarkan kerangka konseptual dalam penelitian ini, maka dapat dibuat hipotesis sebagai berikut:

$\mathrm{H}_{1}$ : Kualitas pelayanan berpengaruh positif signifikan terhadap keputusan konsumen dalam memilih Go-Food

$\mathrm{H}_{2}$ : Pengiklanan berpengaruh positif signifikan terhadap keputusan konsumen dalam memilih Go-Food

$\mathrm{H}_{3}$ : Harga berpengaruh positif signifikan terhadap keputusan konsumen dalam memilih Go-Food

$\mathrm{H}_{4}$ : Kualitas pelayanan, pengiklanan, dan harga secara berpengaruh positif signifikan terhadap keputusan konsumen dalam memilih Go-food

\section{METODE PENELITIAN}

\section{Pendekatan, Jenis, dan Sifat Penelitian}

Jenis penelitian ini adalah penelitian asosiatif yang bertujuan untuk mengetahui pengaruh ataupun juga hubungan antara dua variabel atau lebih. Pendekatan yang digunakan adalah kuantitatif untuk meneliti pada populasi atau sampel yang berbentuk statistik dengan tujuan untuk menguji hipotesis yang telah ditetapkan. 


\section{Tempat dan Waktu Penelitian}

Penelitian ini dilakukan pada konsumen atau pelanggan Go-Food di Kota Medan dan dilakukan pada Februari 2021 sampai dengan Maret 2021.

\section{Populasi dan Sampel}

Populasi dalam penelitian ini ialah seluruh konsumen Go-Food di Kota Medan yang jumlahnya tidak diketahui secara pasti karena tidak adanya data-data jumlah yang pasti dan akurat. Untuk menentukan sampel dengan jumlah populasi yang tidak diketahui dapat digunakan rumus infinitive sebagai berikut:

$$
n=\frac{(Z a)^{2} p q}{d^{2}}
$$

Keterangan:

$n \quad=$ jumlah sampel minimal yang diperlukan

$Z \alpha \quad=$ nilai standar normal yang besarnya tergantung $\alpha$

Bila $\alpha=0,05$ maka $Z=1,96$

Bila $\alpha=0,01$ maka $Z=1,67$

$p \quad=$ proporsi yang diestimasi

$q \quad=1-p$

$d \quad=$ penyimpangan yang ditolerir

Berdasarkan hasil observasi yang dilakukan oleh peneliti pada 100 orang konsumen Go-Food, terdapat 24 orang yang rutin menggunakan layanan Go-Food minimal 1 (satu) kali dalam 1 (satu) minggu. Maka, nilai $p$ adalah 24/30 x 100\% $=72 \%$ dan nilai $q$ adalah $28 \%$. Dengan demikian, jumlah sampel yang mewakili populasi dalam penelitian ini adalah:

$$
\begin{aligned}
& n=\overline{1,96^{2} \cdot 0,72 \cdot 0,28} \\
& n=77,4 \text { yang digenapkan menjadi } 78 \text { orang }
\end{aligned}
$$

\section{Jenis dan Sumber Data}

Penelitian ini menggunakan data primer, sehingga untuk memperoleh data dan informasi yang berhubungan dengan penelitian ini, maka dilakukan pengumpulan data melalui sebagai berikut:
a. Keusioner
b. Observasi
c. Studi Dokumentasi

\section{Identifikasi dan Definisi Operasional Variabel Penelitian}

Adapun identifikasi dan definisi operasional variabel dalam penelitian ini dapat dilihat 
pada Tabel 1.

Tabel 1.

Definisi Operasional dan Pengukuran Variabel

\begin{tabular}{|c|c|c|c|}
\hline Variabel & Definisi Variabel & Indikator & $\begin{array}{c}\text { Skala } \\
\text { Pengukuran }\end{array}$ \\
\hline $\begin{array}{l}\text { Kualitas Pelayanan } \\
\qquad\left(\mathrm{X}_{1}\right)\end{array}$ & $\begin{array}{lrr}\text { Kualitas } & \text { pelayanan } & \text { berfokus } \\
\text { pada upaya } & \text { pemenuhan } \\
\text { kebutuhan dan } & \text { keinginan } \\
\text { konsumen serta } & \text { ketepatan } \\
\text { penyampaianya } & \text { untuk } \\
\text { mengimbangi } & \text { harapan } \\
\text { konsumen. } & \\
& \\
\text { Sumber: Tjiptono (2016) }\end{array}$ & $\begin{array}{|ll|}\text { 1. } & \text { Bukti fisik } \\
\text { 2. } & \text { Reliabilitas } \\
\text { 3. } & \text { Daya tanggap } \\
\text { 4. } & \text { Kompetensi } \\
\text { 5. } & \text { Kesopanan } \\
\text { 6. } & \text { Kredibilitas } \\
\text { 7. } & \text { Keamanan } \\
\text { 8. } & \text { Akses } \\
\text { 9. } & \text { Komunikasi } \\
\text { 10. } & \text { Kemampuan memahami } \\
& \text { pelanggan } \\
& \\
\text { Sumber: Tjiptono (2016) }\end{array}$ & Likert \\
\hline $\begin{array}{l}\text { Pengiklanan } \\
\qquad\left(\mathrm{X}_{2}\right)\end{array}$ & $\begin{array}{|lrr|}\text { Iklan atau pengiklanan } & \text { adalah } \\
\text { bentuk } & \text { komunikasi } & \text { berbayar } \\
\text { yang } & \text { menggunakan } & \text { media } \\
\text { massa } & \text { dan media } & \text { interaktif } \\
\text { untuk } & \text { menjangkau audiens yang } \\
\text { luas } & \text { dalam } & \text { rangka } \\
\text { menghubungkan sponsor yang }\end{array}$ & $\begin{array}{ll}\text { 1. } & \text { Membujuk konsumen } \\
\text { 2. } & \text { Mengingatkan konsumen } \\
\text { 3. } & \text { Musik } \\
\text { 4. } & \text { Visual } \\
\text { 5. } & \text { Waktu penayangan } \\
\text { Sumber: Saladin (2015) }\end{array}$ & Likert \\
\hline & $\begin{array}{l}\text { jelas dengan pembeli (audiens } \\
\text { sasaran) dan memberikan } \\
\text { informasi tentang produk } \\
\text { (barang, jasa, dan gagasan). } \\
\text { Sumber: Moriaty et al. (2014) }\end{array}$ & 6. & \\
\hline $\operatorname{Harga}\left(\mathrm{X}_{3}\right)$ & 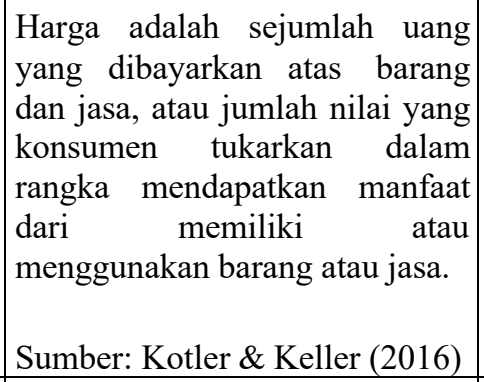 & 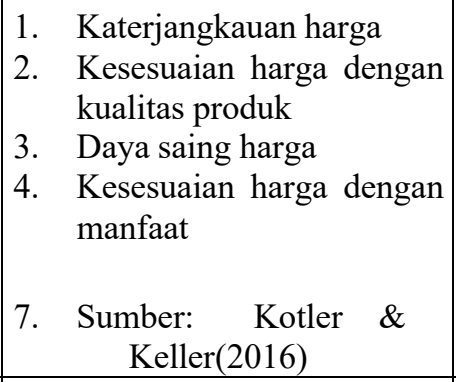 & Likert \\
\hline $\begin{array}{c}\text { Keputusan } \\
\text { Konsu } \\
\text { men (Y) }\end{array}$ & 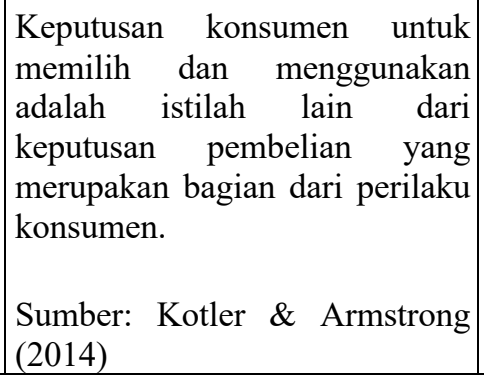 & \begin{tabular}{|ll} 
1. & Kebutuhan \\
2. & Pencarian informasi \\
3. & Evaluasi \\
4. & Keyakinan untuk \\
& menggunakan \\
8. & Menjadi prioritas Sumber: \\
& Sumarwan (2011)
\end{tabular} & Likert \\
\hline
\end{tabular}




\section{PEMBAHASAN}

\section{Gambaran Umum Go-Food}

Go-Food adalah layanan pesan antar makanan terbesar di dunia di luar Cina dan bekerja sama dengan 400,000 merchant di berbagai kota di Indonesia. Terdapat lebih dari 400,000 restoran telah menjadi Go-Food Partner dan resmi bekerja sama dengan Go-Food.

\section{Karakteristik Responden} Tabel 2.

Adapun hasil krakteristik responden dalam penelitian ini dapat dilihat pada

Tabel 2.

Karakteristik Responden

\begin{tabular}{|c|c|c|}
\hline \multicolumn{3}{|c|}{ Jenis Kelamin } \\
\hline Keterangan & Frekuensi & Persentase (\%) \\
\hline Pria & 19 & 24,4 \\
\hline Wanita & 59 & 75,6 \\
\hline Total & 78 & 100,0 \\
\hline \multicolumn{3}{|c|}{ Usia } \\
\hline Keterangan & Frekuensi & Persentase (\%) \\
\hline$<20$ Tahun & 7 & 9,0 \\
\hline 21-25 Tahun & 26 & 33,3 \\
\hline$>26$ Tahun & 45 & 57,7 \\
\hline Total & 78 & 100,0 \\
\hline \multicolumn{3}{|c|}{ Tingkat Pendidikan } \\
\hline Keterangan & Frekuensi & Persentase (\%) \\
\hline SMA & 5 & 6,4 \\
\hline D3 & 15 & 19,2 \\
\hline $\mathrm{S} 1$ & 55 & 70,5 \\
\hline $\mathrm{S} 2$ & 3 & 3,8 \\
\hline Total & 78 & 100,0 \\
\hline \multicolumn{3}{|c|}{ Pekerjaan } \\
\hline Keterangan & Frekuensi & Persentase (\%) \\
\hline Pelajar/Mahasiswa & 20 & 25,6 \\
\hline Karyawan & 53 & 67,9 \\
\hline PNS & 5 & 6,4 \\
\hline Total & 78 & 100,0 \\
\hline
\end{tabular}

Sumber: Data Diolah dengan SPSS (2021) 


\section{Uji Asumsi Klasik Uji Normalitas}

Adapun hasil uji normalitas menggunakan Kolmogorov-Smirnov Test dalam penelitian ini dapat dilihat pada Tabel 3.

\section{Tabel 3.}

\section{Hasil Uji Normalitas dengan Kolmogorov-Smirnov Test}

\section{One-Sample Kolmogorov-Smirnov Test}

\begin{tabular}{llr} 
& & $\begin{array}{c}\text { Unstandardized } \\
\text { Residual }\end{array}$ \\
\hline N & Mean & 78 \\
\cline { 2 - 3 } & Std. Deviation &, 0000000 \\
\hline Most Extreme Differences & Absolute &, 69831740 \\
\cline { 2 - 3 } & Positive &, 071 \\
\cline { 2 - 3 } & Negative &, 071 \\
\hline Test Statistic & &, 051 \\
\hline Asymp. Sig. (2-tailed) & &, 071 \\
\hline a. Test distribution is Normal. & & \\
\hline
\end{tabular}

Sumber: Data Diolah dengan SPSS (2021)

Berdasarkan hasil uji normalitas diatas dapat dilihat bahwa nilai Asymp.Sig. (2tailed) sebesar 0,20 >0,05 sehingga dapat disimpulkan bahwa distribusi data dalam penelitian ini adalah normal. Kemudian hasil uji normalitas menggunakan Histogram dalam penelitian ini dapat dilihat pada Gambar 2.

Sumber: Data Diolah dengan SPSS (2021)

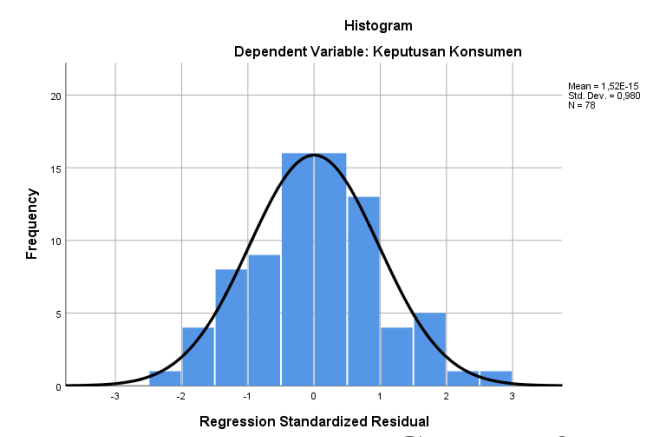

Gambar 2.

\section{Hasil Uji Normalitas dengan Histogram}

Berdasarkan hasil uji normalitas diatas dapat dilihat bahwa histogram tidak condong ke kiri atau ke kanan dan tepat berada diantara atau mengikuti garis diagonal, sehingga dapat disimpulkan bahwa distribusi data dalam penelitian ini adalah normal. Kemudian hasil uji normalitas menggunakan P-P Plot dalam penelitian ini dapat dilihat pada Gambar 3.

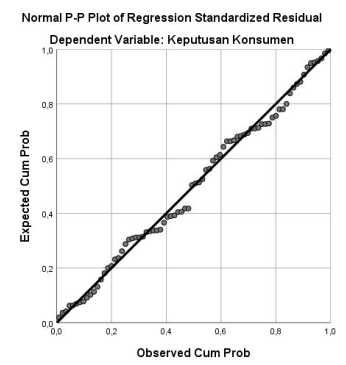

Sumber: Data Diolah dengan SPSS (2021) 
Berdasarkan hasil uji normalitas diatas dapat dilihat bahwa plot tepat berada diantara atau mengikuti garis diagonal, sehingga dapat disimpulkan bahwa distribusi data dalam penelitian ini adalah normal.

\section{Uji Multikolinearitas}

Adapun hasil uji multikolinearitas dalam penelitian ini dapat dilihat pada Tabel 4.

Tabel 4.

\section{Hasil Uji Multikolinearitas}

\section{Coefficients $^{\mathrm{a}}$}

\begin{tabular}{|c|c|c|c|c|c|c|}
\hline \multirow{2}{*}{\multicolumn{2}{|c|}{ Model }} & \multicolumn{2}{|r|}{ (2) } & \multirow{2}{*}{$\begin{array}{c}\text { Standardized } \\
\text { Coefficients } \\
\text { Beta } \\
\end{array}$} & \multicolumn{2}{|c|}{ Collinearity Statistics } \\
\hline & & $\mathrm{B}$ & Std. Error & & Tolerance & \\
\hline & (Constant) & 1,697 & 6,388 & & & \\
\hline & Kualitas Pelayanan & , 149 & ,057 & ,247 & 894 & 1,118 \\
\hline & Pengiklanan & 231 & , 105 & ,199 & ,999 & 1,001 \\
\hline & Harga & ,541 & ,111 & ,463 & 894 & 1,119 \\
\hline
\end{tabular}

Berdasarkan hasil uji multikolinearitas diatas dapat dilihat bahwa nilai tolerance dari masing-masing variabel bebas $>0,1$ dan nilai VIF dari masing-masing variabel bebas $<10$ sehingga dapat disimpulkan bahwa tidak terdapat gejala multikolineritas antar variabel.

\section{Uji Heteroskedastisitas}

Adapun hasil uji heteroskedastisitas dalam penelitian ini dapat dilihat pada Tabel 5.

\section{Tabel 5.}

Hasil Uji Heteroskedastisitas

\section{Coefficients $^{\mathrm{a}}$}

\begin{tabular}{|c|c|c|c|c|c|c|}
\hline \multirow{2}{*}{\multicolumn{2}{|c|}{ Model }} & \multicolumn{2}{|c|}{ Unstandardized Coefficients } & \multirow{2}{*}{$\begin{array}{c}\text { Standardized Coefficients } \\
\text { Beta }\end{array}$} & \multirow[b]{2}{*}{$\mathrm{t}$} & \multirow[b]{2}{*}{ Sig. } \\
\hline & & $\mathrm{B}$ & Std. Error & & & \\
\hline 1 & (Constant) &,- 482 & 3,666 & &,- 131 & 896 \\
\hline & Kualitas Pelayanan & ,022 & ,033 & ,081 & ,666 &, 507 \\
\hline & Pengiklanan &,- 047 &, 060 &,- 090 &,- 784 & ,435 \\
\hline & Harga & ,060 & 064 & ,114 & ,942 &, 350 \\
\hline
\end{tabular}

a. Dependent Variable: ABS

Sumber: Data Diolah dengan SPSS (2021)

Berdasarkan hasil uji heteroskedastisitas diatas dapat dilihat bahwa nilai signifikansi dari masing-masing variabel bebas $>0,05$ sehingga dapat disimpulkanbahwa tidak terdapat gejala heteroskedastisitas antar variabel. Analisis Data Penelitian

\section{Model Penelitian}

Adapun hasil model penelitian menggunakan regresi linear berganda dalam penelitian ini dapat dilihat pada Tabel 6. 


\section{Tabel 6.}

\section{Hasil Regresi Linear Berganda}

\begin{tabular}{|c|c|c|c|c|c|c|c|}
\hline \multicolumn{8}{|c|}{ Coefficients $^{a}$} \\
\hline \multirow[b]{2}{*}{ Model } & \multicolumn{2}{|c|}{ Unstandardized Coefficients } & \multirow{2}{*}{$\begin{array}{l}\text { Standardized } \\
\text { Coefficients } \\
\text { Beta }\end{array}$} & \multirow[b]{2}{*}{$t$} & \multirow[b]{2}{*}{ Sig. } & \multicolumn{2}{|c|}{ Collinearity Statistics } \\
\hline & $\mathrm{B}$ & Std. Error & & & & Tolerance & VIF \\
\hline 1 (Constant) & 1,697 & 6,388 & & ,266 & ,791 & & \\
\hline Kualitas Pelayanan & , 149 & ,057 & ,247 & 2,593 & 011 & ,894 & 1,118 \\
\hline Pengiklanan & ,231 & , 105 & , 199 & 2,199 & ,031 & ,999 & 1,001 \\
\hline Harga & ,541 & ,111 & ,463 & 4,854 & ,000 & ,894 & 1,119 \\
\hline
\end{tabular}

a. Dependent Variable: Keputusan Konsumen

Sumber: Data Diolah dengan SPSS (2021)

Berdasarkan hasil regresi linear berganda tersebut maka dapat dibuat persamaan sebagai berikut:

$$
Y=1,697 C+0,149 X_{1}+0,231 X_{2}+0,541 X_{3}
$$

Melalui persamaan tersebut dapat dijelaskan bahwa apabila nilai kualitas pelayanan, pengiklanan, dan harga adalah 0 (nol), maka nilai keputusan konsumen adalah 1,697. Apabila nilai kualitas pelayanan adalah 1 (satu), maka nilai keputusan konsumen adalah 0,149. Apabila nilai pengiklanan adalah 1 (satu), maka nilai keputusan konsumen adalah 0,231. Apabila nilai harga adalah 1 (satu), maka nilai keputusan konsumen adalah 0,541.

\section{Koefisien Determinasi}

Adapun hasil koefisien determinasi dalam penelitian ini dapat dilihat pada Tabel 7.

\section{Tabel 7. \\ Hasil Koefisien Determinasi}

Model Summary ${ }^{b}$

\begin{tabular}{|c|c|c|c|c|}
\hline \multicolumn{5}{|c|}{ Model Summary } \\
\hline Model & $\mathrm{R}$ & R Square & $\begin{array}{l}\text { Adjusted R } \\
\text { Square }\end{array}$ & $\begin{array}{c}\text { Std. Error of the } \\
\text { Estimate }\end{array}$ \\
\hline 1 &, $631^{a}$ & ,398 & ,373 & 1,732 \\
\hline
\end{tabular}

Sumber: Data Diolah dengan SPSS (2021)

Berdasarkan hasil koefisien determinasi tersebut dapat dijelaskan bahwa nilai Adjusted $R$ Square sebesar 0,373 menunjukkan bahwa dalam penelitian ini kualitas pelayanan, pengikalan, dan harga memiliki kontribusi terhadap keputusan konsumen sebesar $37,3 \%$.

\section{Uji Hipotesis}

Adapun hasil uji hipotesis secara parsial dalam penelitian ini dapat dilihat pada Tabel 8 .

Tabel 8.

Hasil Uji Signifikansi Parsial (Uji-t)

\begin{tabular}{l|r|r|r|r|r} 
& \multicolumn{2}{c}{$\begin{array}{c}\text { Unstandardized Coefficients } \\
\text { Model }\end{array}$} & $\begin{array}{c}\text { Standardized Coefficients } \\
\text { Beta }\end{array}$ & t & Sig. \\
\hline 1 (Constant) & 1,697 & 6,388 & &, 266 &, 791 \\
\hline Kualitas Pelayanan &, 149 &, 057 &, 247 & 2,593 &, 011 \\
\hline Pengiklanan &, 231 &, 105 &, 199 & 2,199 &, 031 \\
\hline Harga &, 541 &, 111 &, 463 & 4,854 &, 000 \\
\hline
\end{tabular}

a. Dependent Variable: Keputusan Konsumen

Sumber: Data Diolah dengan SPSS (2021) 
Berdasarkan hasil uji signifikansi parsial (uji-t) tersebut dapat dilihat bahwa kualitas pelayanan memiliki nilai $t_{\text {hitung }}$ sebesar 2,593 $>t_{\text {tabel }}$ 1,665 dengan tingkat signifikansi sebesar $0,01<0,05$ sehingga dapat disimpulkan bahwa kualitas pelayanan berpengaruh positif signifikan terhadap keputusan konsumen. Kemudian pengiklanan memiliki nilai $t_{\text {hitung }}$ sebesar 2,199 $>t_{\text {tabel }} 1,665$ dengan tingkat signifikansi sebesar 0,03<0,05 sehingga dapat disimpulkan bahwa pengiklanan berpengaruh positif signifikanterhadap keputusan

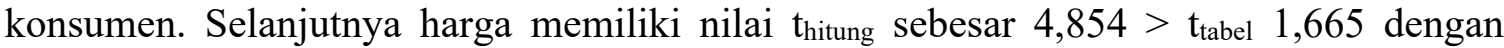
tingkat signifikansi sebesar $0,00<0,05$ sehingga dapat disimpulkan bahwa harga berpengaruh positif signifikan terhadap keputusan konsumen.

Kemudian hasil uji hipotesis secara simultan dalam penelitian ini dapat dilihat pada Tabel 9.

Tabel 9.

Hasil Uji Signifikansi Simultan (Uji-F)

\begin{tabular}{llr|r|r|r|r}
\multicolumn{2}{c}{ ANOVA $^{\text {a }}$} & & \\
Model & Sum of Squares & df & Mean Square & F & Sig. \\
\hline 1 & Regression & 146,628 & 3 & 48,876 & 16,285 &, $000^{\mathrm{b}}$ \\
\cline { 2 - 8 } & Residual & 222,090 & 74 & 3,001 & & \\
\cline { 2 - 8 } & Total & 368,718 & 77 & & & \\
\hline
\end{tabular}

a. Dependent Variable: Keputusan Konsumen

b. Predictors: (Constant), Harga, Pengiklanan, Kualitas Pelayanan

Sumber: Data Diolah dengan SPSS (2021)

Berdasarkan hasil uji signifikansi simultan (uji-F) tersebut dapat dilihat bahwa

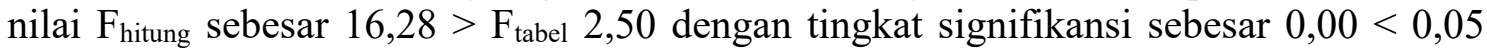
sehingga dapat disimpulkan bahwa dalam penelitian ini secara simultan kualitas pelayanan, pengiklanan, dan harga berpengaruh positif signifikan terhadap keputusan menggunakan.

\section{KESIMPULAN}

Berdasarkan hasil penelitian ini diketahui bahwa kualitas pelayanan berpengaruh positif signifikan terhadap keputusan konsumen dalam memilih Go-Food. Hal ini menunjukkan bahwa Go-Food telah memberikan pelayanan terbaik kepada konsumen, sehingga memikat hati konsumen untuk selalu menggunakan layannnya. Hasilpenelitian ini juga konsisten dengan hasil penelitian yang dilakukan oleh Kaisapitri (2019) yang juga memperoleh hasil bahwa kualitas pelayanan berpengaruh terhadap keputusan konsumen memilih Go-Food. Dari hasil penelitian ini diketahui bahwa pengiklanan berpengaruh positif signifikan terhadap keputusan konsumen dalam memilih Go-Food. Hal ini menunjukkan bahwa Go-Food telah menayangkan iklan terbaik dan diterima oleh konsumen, sehingga memikat hati konsumen untuk menggunakan layannnya. Hasil penelitian ini juga konsisten dengan hasil penelitian yang dilakukan oleh Iisnawati, et.al. (2019) yang juga memperoleh hasil bahwa iklan atau pengiklanan berpengaruh terhadap keputusan konsumen memilih Go-Food. Sedangkan harga berpengaruh positif signifikan terhadap keputusan konsumen dalam memilih Go-Food. Hal ini menunjukkan bahwa Go-Food telah menetapkan harga yang sesuai dan dapat diterima oleh konsumen, sehingga memikat hati konsumen untuk selalu menggunakan layannnya. Hasil penelitian ini juga konsisten dengan hasil penelitian yang dilakukan oleh Ulam (2019) yang juga memperoleh hasil bahwa harga berpengaruh terhadap keputusan konsumen memilih GoFood. 


\section{REFERENSI}

Ghozali, I. 2016. Aplikasi Analisis Multivariate dengan Program IBM SPSS 23.

Semarang: BPFE Universitas Diponegoro.

Gojek.com. 2019. GO-FOOD Join Merchant | Bisnis.

https://www.gojek.com/gofood/business/.

Kotler, P., \& Armstrong, G. 2014. Prinsip-Prinsip Pemasaran. Jakarta: Erlangga.

Kotler, P., \& Keller, K. L. 2016. Marketing Management (Edisi 15 G). England: Pearson Education.

Moriaty, S., Mitchell, N., \& Wells, W. 2014. Advertising. Jakarta: Kencana Prenada Media Group.

Saladin, B. A. \& D. 2015. Manajemen Pemasaran: Ringkasan Praktis, Teori, Aplikasi Dan Tanya Jawab. Bandung: CV. Linda Karya.

Situmorang, S. dan M. L. 2019. Analisis Data: Untuk Riset Manajemen dan Bisnis. Medan: Penerbit USU Press.

Sumarwan, U. 2011. Perilaku Konsumen: Teori dan Penerapannya dalam Pemasaran. Bogor: Ghalia Indonesia.

Tjiptono, F. 2016. Strategi Pemasaran. Yogyakarta: ANDI. 